\title{
A Comparative Study of the Leadership Behavior of Freshman and Final Year Undergraduate Students
}

\section{Mihriay Musa}

Usak University, Faculty of Sport Sciences, Department of Coaching Education, Usak/Turkey. Email:mihriay.musa@usak.edu.tr

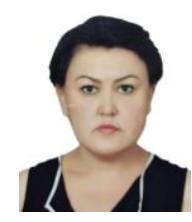

\begin{abstract}
This study was conducted to examine the leadership levels of university students by comparing them according to various variables. In our research, both qualitative and quantitative methods were used with the scanning model. The universe of the study consisted of the freshman and final year undergraduate students studying at Akdeniz University in the 2019-20 academic year. A simple random sampling method was used to determine the study group. The research sample determined in this way was composed of 175 students studying in the first and last years of the Faculty of Sport Sciences, Teaching, Coaching, Management, and Recreation Departments, respectively. In this study, the Leadership Qualities Scale, which was developed by Cansoy and Turan (2016) and consists of 28 questions, was used. Kruskal Wallis H test and Mann-Whitney U tests, which are nonparametric, were used to analyze the data. The leadership level of the students was found to be high. A difference was determined in leadership sub-dimensions. To eliminate these differences; self-confidence levels of teaching, sports management, and recreation department students; the level of responsibility of the students of teaching, coaching and recreation departments; the reliability levels of male students and the persuasion skills of firstyear students should be increased.
\end{abstract}

Keywords: Sport, Leadership, Student, Behavior, Self-confidence, Reliability.

Citation | Mihriay Musa (2020). A Comparative Study of the Leadership Behavior of Freshman and Final Year Undergraduate Students. Asian Journal of Education and Training, 6(4): 627-635. History:

Received: 10 September 2020

Revised: 8 October 2020

Accepted: 27 October 2020

Published: 16 November 2020

Licensed: This work is licensed under a Creative Commons Attribution 3.0 License $($ (c) $)$

Publisher: Asian Online Journal Publishing Group
Funding: This study received no specific financial support.

Competing Interests: The author declares that there are no conflicts of interests regarding the publication of this paper.

Transparency: The author confirms that the manuscript is an honest, accurate, and transparent account of the study was reported; that no vital features of the study have been omitted; and that any discrepancies from the features of the study have been omitted
study as planned have been explained.

study as planned have been explained.
Ethical: This study follows all ethical practices during writing.

\section{Contents}

1. Introduction

References. 


\section{Contribution of this paper to the literature}

This study contributes to existing literature by examining the leadership levels of university students and comparing them according to various variables.

\section{Introduction}

Compared to the time in the existence of humanity, the equivalent of the concept of "Leadership" has come up to the present day with those written on the sanction power and political existence of the British government after the 1850s. On the contrary, "Management" in the current time is an advanced phenomenon within the complex of activities that emerged in the recent era. Also, it is the behavior of the world, whose focus is work, as a model person who is respected as a "manager" (M. Bayansalduz., Afyon, Kepoglu, Dalli, \& Mulazimoglu, 2014; Bingol \& Bayansalduz, 2016; Can, Soyer, \& Bayansalduz, 2009). Leadership is the behavior of an individual who manages the activities of the group to achieve a common goal (Hemphill \& Coons, 1957). Leadership is "the process of interpersonal interaction and orientation that emerges in the direction of achieving a certain goal or goals through communication" (Tannenbaum, Weschler, \& Massarik, 1961). Leadership is "the process of influencing the activities of a group organized to achieve a predetermined goal" (Rauch \& Behling, 1984). Four basic elements are emerging in leadership definitions. These are purpose, leader, audience and environment of 4 basic elements; we can define goals as interests and needs that bring group members together and keep them connected; leader as the organizational element that can influence the elements that make up the group; followers (members) as people who acknowledge the leader's influence; environment as the competence of the members, the level of relationships, the realization of the goals, and the level of motivation (Bayansalduz., M., 2014; Eraslan, Ozmaden, Bayansalduz, Goktepe, \& Koc, 2015). Leader; an individual given a formal status by election, appointment, succession, transfer or other means; leadership means the achievement of behaviors that help the group reach its goal by one or more people in a group (Baykal, 1995). Although the word "onderlik" was suggested in Turkish as an equivalent to this concept, which passes from the English word "leadership" to Turkish as leadership; the word "leadership" is generally used (Sisman, 1997). Kouzes and Posner in their research, the six most important characteristics that an effective leader should have; to be honest, to have a vision, to be able to mobilize others, to be self-confident, to be open-minded and supportive (Cacioppe, 1997). Gender is characterized as the innate differences between men and women. It is known that there are psychological and cultural differences between women and men in society, apart from biological differences. Studies suggest that the leadership traits of men are more dominant. On the other hand, results have been obtained that the leadership characteristics of women are slightly lower than men. The reason for this was determined to be due to gender differences. Gender is biological. The transition to social life is determined socially. It describes the biological psychological and sociological characteristics of women and men. Thus, the gender inequality of society becomes natural with the characteristics of femininity and masculinity attributed to the gender (Adacay, 2014; Akpinar, Bayansalduz, \& Toros, 2012; Sahin, 2019). In our study, we will evaluate the leadership values of students on the following main characteristics that a leader should have.

Persuasion Skill: Leaders should have a personality that paves the way for people, creates a sense of loyalty among them, creates a feeling of turning towards the same goal and making it a struggle to achieve that goal, he should have a different color, depth, mental and social abilities, communication and persuasion skills than ordinary people, and see others' benefits above his interests (Findikci, 2009). A leader has to be effective in both verbal and non-verbal communication, that is, in interpersonal communication. Leadership requires a leader to be able to impose himself on the people around him, to listen to his words, to direct them and to communicate effectively with them (Gezgin \& Yalcin, 2018).

Self Confidence: Leaders know what they want, do more than their goals. It means struggling with difficulties, struggling for ideals, working towards achieving goals and looking to the future with confidence (Bayansalduz, 2012; Konter, $\mathrm{Ng}$, \& Bayansalduz, 2013; Yukl, 2010).

Ability to work with a group: It is the ability to direct a team or a group or an individual, to start an activity, to organize and plan, to take responsibility, to coordinate, to encourage others, to set goals, to play a positive role as a team or group member. Leaders set goals and focus the group on a common vision. At the same time, leaders share, act respectfully, and resolve conflicts (Adair., 2011).

Trustworthiness: This feature is the integrity and values of the individual's behaviors and actions, the soundness of his moral character, makes him a reliable person (Adair, 2003; Northouse, 2010; Yukl, 2010). Confidence behavior is one of the important characteristics for interacting with the people around (Derks, Lee, \& Krabbendam, 2014; Soyer, Bayansalduz, \& Toros, 2012). It is helping others, sharing and listening to troubles, building intimate relationships based on trust.

Problem Solving Skills: This skill is defining the problem in real terms, determining appropriate information or limitations, presenting possible options or solutions, solving the problem, controlling the solution and sharing the results (OECD, 2014).

Responsibility: It is the responsibility of individuals and groups for the well-being of others (Dugan \& Komives, 2007). Leaders should be interested in social problems, work for their country, respect the rights of others, and be aware of their obligations.

\section{Method}

This research is in scanning model. The measurement tools used in the study, the research model, population and sample, data collection tools, data collection, statistical methods for data analysis and data analysis are included. The study was conducted in a scanning model. Survey models are a research method designed to examine the past or present in the sample group selected from the universe containing large groups (Karasar, 1999). The main body of the study was applied to 1st and 4th grade students studying at Akdeniz University, Faculty of Sport Sciences, Physical Education and Sports Teaching, Sports Management, Recreation and coaching in the 2019-20 academic year. The sample mass of the study consists of 175 people randomly selected from the 1st and 4th grade students of the Physical Education and Sports Teaching, Recreation, Sports Management and Coaching departments of the Faculty of Sport Sciences of Akdeniz University. The Leadership Qualities Scale used in this 
study was developed by Cansoy and Turan (2016). Leadership Traits Scale was developed on the basis of seven different leadership scales in the literature. As the premise of the scale, 51 items were created within the framework of content validity (expert opinions) and some items were removed from the scale as a result of the applications. As a result of the factor analysis performed later, it was seen that there were 6 sub-dimensions with eigenvalues above 1. In addition, since the factor weights of 23 of the 51 items in the measurement tool were below .45, the final version of the scale was determined as 28 items. The sub-dimensions obtained were named as self-confidence, ability to work with a group, trustworthiness, persuasion skill, problem solving and responsibility, respectively. The scale form has a 5-point Likert rating according to the frequency of the behavior shown: Always (5), Frequently (4), Occasionally (3), Very rare (2), Never (1). It is emphasized that there is a positive and significant relationship among all sub-dimensions (self-confidence, ability to work with a group, trustworthiness, persuasion skill, problem solving and responsibility) in the Leadership Qualities Scale. On the other hand, as a result of the reliability analysis; .83 of self-confidence sub-dimension; the sub-dimension of ability to work with groups .86; reliability subscale .85 ; the sub-dimension of persuasion capability was .59; the sub-dimension of problem solving. 66 and responsibility sub-dimension was reported to have a Cronbach Alpha internal consistency coefficient of .71. The total Cronbach Alpha internal consistency coefficient of the Leadership Qualities Scale was calculated as .92. The data regarding this validity and reliability reveal that the Leadership Qualities Scale is a valid and reliable measurement tool. It is seen that only the persuasion sub-dimension has an internal consistency coefficient of .59. In the questionnaire application, a personal information form consisting of 7 questions was developed and applied to the students in order to learn the gender, class, number of siblings, department, mother's education status, father's education status and the place where they live. In the data analysis, descriptive statistical methods such as frequency $(\mathrm{n})$, percentage (\%), arithmetic mean $(\overline{\mathrm{X}})$ and standard deviation $(\mathrm{S})$ were used in data analysis. A single sample $t$ test of 0.05 was used at 0.05 significance level to determine whether the sample mass represents the main mass equally and homogeneously. As a result of the analysis, it was determined that the sample mass represented the main mass equally and homogeneously. $(\mathrm{p}<0.05)$. The reliability of the scale in our study - Cronbach's Alpha 0.919 , ie $91 \%$, was found to be quite high. In order to determine the validity of the scale related to our study, Extraction Method: Principal Component Analysis was applied. In the explained total variance table, it is stated that the scale consists of 6 factors, and this factor explains to be measured fact as 1st factor 33,44; 2nd factor 8.22; 3rd factor 6,11 ; 4 th factor 4.53 ; the 5 th factor explained 4.15 , and the 6 th factor 4.05 . In addition, this survey, consisting of 6 factors and 28 questions, measures the leadership level of students at a rate of $60.52 \%$. The Shapiro Wilk test was used as $\mathrm{n}>30$ as a result of the normality test performed regarding the data. It was understood that the data did not show normal distribution $(\mathrm{p}>0.05)$. While analyzing the data obtained in this situation, Mann Whitney $\mathrm{U}$ was used to determine whether there was a significant difference between the two groups and the Kruskal Wallis Test at 0.05 significance level to determine whether there was a significant difference between more than two groups.

\section{Findings}

Table-1..Leadership levels of the students.
\begin{tabular}{l|c|c|c}
\hline Variable & $\mathbf{N}$ & Mean & SD \\
\hline Leadership Levels & 175 & 104,38 & 16,12 \\
\hline Note: Mean: Arithmetic Mean, SD: standard deviation
\end{tabular}

Note: Mean: Arithmetic Mean, SD: standard deviation.

As seen in Table 1, students' general leadership levels $\left(\mathrm{x}^{-}=104.38\right)$ are at a high level.

\begin{tabular}{|c|c|c|c|c|}
\hline Variables & Groups & $\mathbf{N}$ & Mean & Std. D. \\
\hline \multirow{2}{*}{ Gender } & Male & 90 & 104,23 & 17,85 \\
\hline & Female & 85 & 104,54 & 14,16 \\
\hline \multirow{2}{*}{ Class } & 1st grade & 88 & 103,91 & 15,38 \\
\hline & 4th grade & 87 & 104,86 & 16,91 \\
\hline \multirow{5}{*}{ Number of Siblings } & None & 24 & 101,46 & 19,74 \\
\hline & 1-2 Siblings & 89 & 106,04 & 13,46 \\
\hline & 3-4 Siblings & 44 & 101,18 & 19,38 \\
\hline & 5-6 Siblings & 16 & 107,63 & 12,94 \\
\hline & 7 and more siblings & 2 & 110,00 & 22,63 \\
\hline \multirow{4}{*}{ Department } & Coaching & 37 & 99,81 & 16,76 \\
\hline & Sports Management & 46 & 107,89 & 12,88 \\
\hline & Recreation & 35 & 102,00 & 14,16 \\
\hline & Teaching & 57 & 105,98 & 18,47 \\
\hline \multirow{5}{*}{ Mother Education Status } & Illiterate & 9 & 105,67 & 11,80 \\
\hline & Primary & 63 & 103,68 & 15,33 \\
\hline & Secondary & 37 & 107,35 & 12,58 \\
\hline & High School & 43 & 104,40 & 20,13 \\
\hline & Undergraduate & 23 & 101,00 & 16,75 \\
\hline \multirow{6}{*}{ Father Education Status } & Illiterate & 3 & 103,00 & 3,61 \\
\hline & Primary & 44 & 102,02 & 12,83 \\
\hline & Secondary & 42 & 104,31 & 15,97 \\
\hline & High School & 54 & 105,17 & 18,60 \\
\hline & Undergraduate & 30 & 106,73 & 17,47 \\
\hline & Master - PhD & 2 & 103,50 & 3,54 \\
\hline \multirow{4}{*}{ Place of Accommodation } & Private dormitory & 14 & 104,57 & 14,20 \\
\hline & Government dormitory & 33 & 101,18 & 11,66 \\
\hline & House & 119 & 104,96 & 17,60 \\
\hline & Apart-house & 9 & 108,22 & 11,98 \\
\hline
\end{tabular}

Considering students' gender, it can be said that women have higher leadership levels. In terms of class, it can be said that the fourth graders have a higher leadership level. In terms of the number of siblings, it can be said that 
those with 1-2 siblings have a higher leadership level. In terms of the department, it can be said that the sports management department has a higher leadership level. In terms of mother's education status, it can be said that those whose mothers are secondary school graduates have higher leadership levels. In terms of the father's educational status, it can be said that those whose fathers are graduates have higher leadership levels. In terms of accommodation, it can be said that those staying in apartments have higher leadership levels.

Table-3. Students' leadership sub-dimensions' levels.

\begin{tabular}{l|c|c|c}
\hline Leadership Sub-Dimensions & N & Mean & SD \\
\hline Sub-dimension of Self-confidence & 175 & 29,31 & 5,29 \\
\hline Sub-dimension of Ability to Work with a Group & 175 & 26,77 & 4,61 \\
\hline Sub-dimension of Trustworthiness & 175 & 19,32 & 3,48 \\
\hline Sub-dimension of Persuasion Ability & 175 & 9,82 & 2,57 \\
\hline Sub-dimension of Problem Solving & 175 & 11,32 & 2,24 \\
\hline Sub-dimension of Responsibility & 175 & 7,85 & 1,63 \\
\hline
\end{tabular}

Note: Mean: Arithmetic Mean, SD: standard deviation.

It can be said that students have high levels of self-confidence, ability to work with the group, trustworthiness, persuasion ability, problem solving and responsibility sub-dimensions of leadership.

Table-4. Analysis of the differences between students' departments, leadership and leadership sub-dimensions.

\begin{tabular}{|c|c|c|c|c|c|c|}
\hline & Department & $\mathbf{N}$ & Mean & $\mathbf{X}^{2}$ & SD & $p$ \\
\hline \multirow{5}{*}{ Leadership Scores } & Coaching & 37 & 74,66 & \multirow{5}{*}{8,40} & \multirow{5}{*}{3} & \multirow{5}{*}{0,039} \\
\hline & Sports Management & 46 & 99,66 & & & \\
\hline & Recreation & 35 & 75,14 & & & \\
\hline & Teaching & 57 & 95,14 & & & \\
\hline & Total & 175 & & & & \\
\hline \multirow{5}{*}{ Sub-dimension of Self-Confidence } & Coaching & 37 & 81,99 & \multirow{4}{*}{8,92} & \multirow{4}{*}{3} & \multirow{4}{*}{0,03} \\
\hline & Sports Management & 46 & 95,6 & & & \\
\hline & Recreation & 35 & 68,47 & & & \\
\hline & Teaching & 57 & 97,76 & & & \\
\hline & Total & 175 & & & & \\
\hline \multirow{5}{*}{ Sub-Dimension of Ability to work with the group } & Coaching & 37 & 69,74 & \multirow{5}{*}{6,41} & \multirow{5}{*}{3} & \multirow{5}{*}{0,093} \\
\hline & Sports Management & 46 & 91,68 & & & \\
\hline & Recreation & 35 & 90,31 & & & \\
\hline & Teaching & 57 & 95,46 & & & \\
\hline & Total & 175 & & & & \\
\hline \multirow{5}{*}{ Sub-Dimension of Trustworthiness } & Coaching & 37 & 77,05 & \multirow{5}{*}{5,05} & \multirow{5}{*}{3} & \multirow{5}{*}{0,168} \\
\hline & Sports Management & 46 & 100,87 & & & \\
\hline & Recreation & 35 & 83,33 & & & \\
\hline & Teaching & 57 & 87,59 & & & \\
\hline & Total & 175 & & & & \\
\hline \multirow{5}{*}{ Sub-dimension of Persuasion Ability } & Coaching & 37 & 78,05 & \multirow{5}{*}{2,40} & \multirow{5}{*}{3} & \multirow{5}{*}{0,494} \\
\hline & Sports Management & 46 & 90,74 & & & \\
\hline & Recreation & 35 & 85,6 & & & \\
\hline & Teaching & 57 & 93,72 & & & \\
\hline & Total & 175 & & & & \\
\hline \multirow{5}{*}{ Sub-dimension of Problem Solving } & Coaching & 37 & 78,97 & \multirow{5}{*}{5,14} & \multirow{5}{*}{3} & \multirow{5}{*}{0,162} \\
\hline & Sports Management & 46 & 99,34 & & & \\
\hline & Recreation & 35 & 77,96 & & & \\
\hline & Teaching & 57 & 90,88 & & & \\
\hline & Total & 175 & & & & \\
\hline \multirow{5}{*}{ Sub-dimension of Responsibility } & Coaching & 37 & 72,73 & \multirow{5}{*}{7,92} & \multirow{5}{*}{3} & \multirow{5}{*}{0,048} \\
\hline & Sports Management & 46 & 96,77 & & & \\
\hline & Recreation & 35 & 78,93 & & & \\
\hline & Teaching & 57 & 96,4 & & & \\
\hline & Total & 175 & & & & \\
\hline
\end{tabular}

Note: Mean: Arithmetic Mean, SD: standard deviation, $\mathrm{p}>0,05$.

There is a significant difference between the leadership levels of students and their departments $(\mathrm{x} 2=8.40 ; \mathrm{p}=$ $0.39<0.05)$. The students of the sports management department have more leadership characteristics than the students of the other departments. On the other hand, the students of the recreation department also have fewer leadership characteristics than the students of other departments.

There is a significant difference between the self-confidence levels of students and their departments $(\mathrm{x} 2=$ 8.92; $\mathrm{p}=0.30<0.05)$. Teaching department students have higher self-confidence than other department students. On the other hand, the students in the recreation department have less self-confidence than the students of other departments. $0.05)$.

There is no significant difference between the students' ability to work with a group and their departments ( $\mathrm{p}>$

There is no significant difference between students' level of trustworthiness and their departments ( $\mathrm{p}>0.05)$.

There is no significant difference between the persuasion ability levels and departments of students ( $\mathrm{p}>0.05)$.

There is no significant difference between students' problem-solving levels and their departments $(\mathrm{p}>0.05)$.

There is a significant difference between students' levels of responsibility and their departments $(\mathrm{x} 2=7.92 ; \mathrm{p}=$ $0.48 ; \mathrm{p}<0.05)$. The students of the department of sports management have more responsibility than the students of 
other departments. On the other hand, the students in the coaching department have less responsibility than the students of other departments.

\begin{tabular}{|c|c|c|c|c|c|c|}
\hline Sub-Dimensions & Gender & $\mathbf{N}$ & $\bar{X}$ & $\mathbf{S}$ & $\mathrm{t}$ & $\mathbf{p}$ \\
\hline \multirow{2}{*}{ Ability to work with a Group } & Male & 90 & 3,79 & 76 & \multirow{2}{*}{,- 752} & \multirow{2}{*}{.130} \\
\hline & Female & 85 & 3,87 & ,63 & & \\
\hline \multirow{2}{*}{ Self-Confidence } & Male & 90 & 3,67 &, 77 & \multirow{2}{*}{1,04} & \multirow{2}{*}{.218} \\
\hline & Female & 85 & 3,56 & ,63 & & \\
\hline \multirow{2}{*}{ Problem Solving } & Male & 80 & 3,80 & ,79 & \multirow{2}{*}{,- 702} & \multirow{2}{*}{.584} \\
\hline & Female & 78 & 3,88 & ,76 & & \\
\hline \multirow{2}{*}{ Persuasion Skill } & Male & 90 & 3,45 & ,87 & \multirow{2}{*}{1,44} & \multirow{2}{*}{.807} \\
\hline & Female & 85 & 3,27 & ,85 & & \\
\hline \multirow{2}{*}{ Trustworthiness } & Male & 90 & 3,96 & ,72 & \multirow{2}{*}{-1.76} & \multirow{2}{*}{.897} \\
\hline & Female & 85 & 4,15 &, 67 & & \\
\hline \multirow{2}{*}{ Responsibility } & Male & 90 & 3,35 & 1,01 & \multirow{2}{*}{.176} & \multirow{2}{*}{.964} \\
\hline & Female & 85 & 3,32 &, 97 & & \\
\hline
\end{tabular}

As seen in Table 5 , there was no statistically significant difference between the level of students' ability to work with the group $(\mathrm{p}=, 130 ; \mathrm{p}<0.05)$, self-confidence $(\mathrm{p}=, 218 ; \mathrm{p}>0.05)$, problem solving $(\mathrm{p}=, 584 ; \mathrm{p}>0.05)$, persuasion ability $(\mathrm{p}=, 807 ; \mathrm{p}>0.05)$, reliability $(\mathrm{p}=$, 897; $\mathrm{p}>0.05)$, and responsibility ( $=, 964 ; \mathrm{p}>0.05)$ subdimensions.

Table-6. Analysis of the difference between students' classes and the levels of the "persuasion ability sub-dimension".

\begin{tabular}{|c|c|c|c|c|c|c|}
\hline Sub-Dimensions & Grade & $\mathbf{N}$ & $\bar{X}$ & $\mathbf{S}$ & $\mathbf{t}$ & $\mathbf{p}$ \\
\hline \multirow{2}{*}{ Ability to work with a Group } & 1st Grade & 88 & 3,90 & ,69 & \multirow{2}{*}{1,32} & \multirow{2}{*}{.99} \\
\hline & 4th Grade & 87 & 3,76 & 71 & & \\
\hline \multirow{2}{*}{ Self-Confidence } & 1st Grade & 88 & 3,51 & ,67 & \multirow{2}{*}{$-1,19$} & \multirow{2}{*}{.47} \\
\hline & 4th Grade & 87 & 3,72 & ,73 & & \\
\hline \multirow{2}{*}{ Problem Solving } & 1st Grade & 88 & 3,79 & ,83 & \multirow{2}{*}{,- 829} & \multirow{2}{*}{.07} \\
\hline & 4th Grade & 70 & 3,89 & 7,71 & & \\
\hline \multirow{2}{*}{ Persuasion Skill } & 1st Grade & 88 & 3,26 & ,83 & \multirow{2}{*}{$-1,63$} & \multirow{2}{*}{.47} \\
\hline & 4th Grade & 87 & 3,47 & ,89 & & \\
\hline \multirow{2}{*}{ Trustworthiness } & 1st Grade & 90 & 4,10 & 7,75 & \multirow{2}{*}{.885} & \multirow{2}{*}{.27} \\
\hline & 4th Grade & 85 & $4, \mathrm{OO}$ & ,66 & & \\
\hline \multirow{2}{*}{ Responsibility } & 1st Grade & 90 & 3,42 & 1,01 & \multirow{2}{*}{1.11} & \multirow{2}{*}{.64} \\
\hline & 4th Grade & 85 & 3,25 & ,97 & & \\
\hline
\end{tabular}

Note: $\mathrm{p}>0,05, \bar{x}:$ Mean.

Table-7. Comparison of the sub-dimensions of the leadership scale of Akdeniz University Faculty of Sport Sciences students according to place of accommodation.

\begin{tabular}{|c|c|c|c|c|c|c|c|c|}
\hline Dimensions & $\begin{array}{l}\text { Place of } \\
\text { Accommodation }\end{array}$ & $\mathbf{N}$ & $\bar{X}$ & $\mathbf{S}$ & SD & $\mathbf{F}$ & $\mathbf{p}$ & Levene $p>.05$ \\
\hline \multirow{4}{*}{ Ability to work with a group } & Private dormitory & 14 & 4,03 & 0,58 & \multirow{4}{*}{$3-171$} & \multirow{4}{*}{0,37} & \multirow{4}{*}{.768} & \multirow{4}{*}{1.71} \\
\hline & $\begin{array}{l}\text { Government } \\
\text { dormitory }\end{array}$ & 33 & 3,90 & 0,50 & & & & \\
\hline & House & 119 & 3,92 & 0,74 & & & & \\
\hline & Apart-house & 9 & 4,13 & 0,41 & & & & \\
\hline \multirow{4}{*}{ Self-Confidence } & Private dormitory & 14 & 3,51 & 0,45 & \multirow{4}{*}{$3-171$} & \multirow{4}{*}{0,94} & \multirow{4}{*}{.420} & \multirow{4}{*}{1.70} \\
\hline & $\begin{array}{l}\text { Government } \\
\text { dormitory }\end{array}$ & 33 & 3,46 & 0,61 & & & & \\
\hline & House & 119 & 3,65 & 0,76 & & & & \\
\hline & Apart-house & 9 & 3,81 & 0,61 & & & & \\
\hline \multirow{4}{*}{ Problem Solving } & Private dormitory & 12 & 3,76 & 0,81 & \multirow{4}{*}{$3-154$} & \multirow{4}{*}{1,19} & \multirow{4}{*}{.314} & \multirow{4}{*}{1.15} \\
\hline & $\begin{array}{l}\text { Government } \\
\text { dormitory }\end{array}$ & 26 & 3,40 & 0,65 & & & & \\
\hline & House & 111 & 3,70 & 0,76 & & & & \\
\hline & Apart-house & 9 & 3,68 & 0,99 & & & & \\
\hline \multirow{4}{*}{ Persuasion Skill } & Private dormitory & 14 & 3,54 & 0,73 & \multirow{4}{*}{$3-171$} & \multirow{4}{*}{0,24} & \multirow{4}{*}{.863} & \multirow{4}{*}{1.58} \\
\hline & $\begin{array}{l}\text { Government } \\
\text { dormitory }\end{array}$ & 33 & 3,32 & 0,80 & & & & \\
\hline & House & 119 & 3,36 & 0,92 & & & & \\
\hline & Apart-house & 9 & 3,29 & 0,53 & & & & \\
\hline \multirow{4}{*}{ Trustworthiness } & Private dormitory & 14 & 4,15 & 0,53 & \multirow{4}{*}{$3-171$} & \multirow{4}{*}{0,56} & \multirow{4}{*}{.641} & \multirow{4}{*}{1.75} \\
\hline & $\begin{array}{l}\text { Government } \\
\text { dormitory }\end{array}$ & 33 & 4,01 & 0,50 & & & & \\
\hline & House & 119 & 4,03 & 0,53 & & & & \\
\hline & Apart-house & 9 & 4,31 & 0,70 & & & & \\
\hline \multirow{4}{*}{ Responsibility } & Private dormitory & 14 & 3,28 & 1,10 & \multirow{4}{*}{$3-171$} & \multirow{4}{*}{0.83} & \multirow{4}{*}{.472} & \multirow{4}{*}{0.60} \\
\hline & $\begin{array}{l}\text { Government } \\
\text { dormitory }\end{array}$ & 33 & 3,10 & 0,91 & & & & \\
\hline & House & 119 & 3,41 & 0,98 & & & & \\
\hline & Apart-house & 9 & 3,27 & 1,17 & & & & \\
\hline
\end{tabular}

Note: $\mathrm{p}>0,05, \bar{x}:$ Mean. 
As seen in Table 6, opinions of the students participating in the study on the dimensions of ability to work with a group $[\mathrm{t}(173)=1.32, \mathrm{p}>.05]$; self-confidence $[\mathrm{t}(173)=-1.19, \mathrm{p}>.05]$; problem solving $[\mathrm{t}(173)=-.829, \mathrm{p}>$ $.05]$; persuasion skill $[\mathrm{t}(173)=-1.63, \mathrm{p}>.05]$; trustworthiness $[\mathrm{t}(173)=.885, \mathrm{p}>.05]$, and responsibility $[\mathrm{t}$ $(173)=1.11, \mathrm{p}>.05]$ do not differ significantly according to their grades. Hence, being fourth grade and first grade do not have a significant determinant role on students' leadership behaviors.

As seen in Table 7 , as a result of one-way variance analysis performed to determine whether there is a difference according to the place of accommodation of the students; it was concluded that the mean scores obtained from the sub-dimensions of ability to work with groups $[\mathrm{F}(3-171)=0.37 ; \mathrm{p}>.05]$; Self-confidence $[\mathrm{F}(3-171)=$ 0.94; $>$ > .05] Problem Solving $[\mathrm{F}(3-171)=1,19 ; \mathrm{p}>$.05] and Persuasion Ability $[\mathrm{F}(3-371)=0.24 ; \mathrm{p}>.05]$; Trustworthiness $[\mathrm{F}(3-171)=0.56 ; \mathrm{p}>.05]$; and Responsibility $[\mathrm{F}(3-171)=0.83 ; \mathrm{p}>.05]$ did not differ significantly in terms of their accommodation.

Table-8. Comparison of the leadership characteristics sub-dimension scores of Akdeniz University Faculty of Sport Sciences students according to the number of siblings of the students.

\begin{tabular}{|c|c|c|c|c|c|c|c|}
\hline Dimensions & $\begin{array}{l}\text { Number of } \\
\text { Siblings }\end{array}$ & $\mathbf{N}$ & $\bar{X}$ & $\mathbf{S}$ & Std. D. & $\mathbf{F}$ & p \\
\hline \multirow{4}{*}{ Ability to Work with a Group } & None & 24 & 3,84 & 0,77 & \multirow{4}{*}{$3-171$} & \multirow{4}{*}{1,19} & \multirow{4}{*}{, 315} \\
\hline & $1-2$ & 89 & 3,99 & 0,58 & & & \\
\hline & $3-4$ & 44 & 3,81 & 0,82 & & & \\
\hline & 5 and more & 18 & 4,09 & 0,52 & & & \\
\hline \multirow{4}{*}{ Self-Confidence } & None & 24 & 3,52 & 0,91 & \multirow{4}{*}{$3-171$} & \multirow{4}{*}{2,12} & \multirow{4}{*}{,315 } \\
\hline & $1-2$ & 89 & 3,69 & 0,60 & & & \\
\hline & $3-4$ & 44 & 3,43 & 0,78 & & & \\
\hline & 5 and more & 18 & 3,83 & 0,63 & & & \\
\hline \multirow{4}{*}{ Problem Solving } & None & 24 & 3,60 & 0,81 & \multirow{4}{*}{$3-154$} & \multirow{4}{*}{,078 } & \multirow{4}{*}{, 972} \\
\hline & $1-2$ & 82 & 3,64 & 0,72 & & & \\
\hline & $3-4$ & 39 & 3,69 & 0,88 & & & \\
\hline & 5 and more & 16 & 3,68 & 0,68 & & & \\
\hline \multirow{4}{*}{ Persuasion Skill } & None & 24 & 3,19 & 0,79 & \multirow{4}{*}{$3-171$} & \multirow{4}{*}{,586 } & \multirow{4}{*}{,625 } \\
\hline & $1-2$ & 89 & 3,44 & 0,87 & & & \\
\hline & $3-4$ & 44 & 3,34 & 0,90 & & & \\
\hline & 5 and more & 18 & 3,29 & 0,87 & & & \\
\hline \multirow{4}{*}{ Trustworthiness } & None & 24 & 3,94 & 0,76 & \multirow{4}{*}{$3-171$} & \multirow{4}{*}{, 778} & \multirow{4}{*}{.541} \\
\hline & $1-2$ & 89 & 4,10 & 0,62 & & & \\
\hline & $3-4$ & 44 & 3,95 & 0,84 & & & \\
\hline & 5 and more & 18 & 4,18 & 0,57 & & & \\
\hline \multirow{4}{*}{ Responsibility } & None & 24 & 3,22 & 1,12 & \multirow{4}{*}{$3-171$} & \multirow{4}{*}{1,06} & \multirow{4}{*}{.377} \\
\hline & $1-2$ & 89 & 3,34 & 0,92 & & & \\
\hline & $3-4$ & 44 & 3,40 & 1,10 & & & \\
\hline & 5 and more & 18 & 3,09 & 0,82 & & & \\
\hline
\end{tabular}

Note: $\mathrm{p}>0,05, \bar{x}$ : Mean.

Table-9. Comparison of the leadership characteristics sub-dimension scores of Akdeniz University Faculty of Sport Sciences students according to the education levels of mothers of the students.

\begin{tabular}{|c|c|c|c|c|c|c|c|}
\hline Dimensions & Mother Education Status & $\mathbf{N}$ & $\bar{X}$ & $\mathbf{S}$ & Std. D. & $\mathbf{F}$ & $\mathbf{p}$ \\
\hline \multirow{5}{*}{ Ability to Work with a Group } & Illiterate & 9 & 4,25 & 0,24 & \multirow{5}{*}{$4-140$} & \multirow{5}{*}{1,01} & \multirow{5}{*}{,401 } \\
\hline & Primary & 63 & 3,93 & 0,68 & & & \\
\hline & Secondary & 37 & 4,03 & 0,57 & & & \\
\hline & High School & 43 & 3,89 & 0,80 & & & \\
\hline & Undergraduate & 23 & 3,78 & 0,63 & & & \\
\hline \multirow{5}{*}{ Self-confidence } & Illiterate & 9 & 3,61 & 0,52 & \multirow{5}{*}{$4-170$} & \multirow{5}{*}{,298 } & \multirow{5}{*}{,879 } \\
\hline & Primary & 63 & 3,58 & 0,70 & & & \\
\hline & Secondary & 37 & 3,71 & 0,54 & & & \\
\hline & High School & 43 & 3,63 & 0,86 & & & \\
\hline & Undergraduate & 23 & 3,52 & 0,71 & & & \\
\hline \multirow{5}{*}{ Problem Solving } & Illiterate & 9 & 3,57 & 0,75 & \multirow{5}{*}{$4-170$} & \multirow{5}{*}{, 161} & \multirow{5}{*}{, 958} \\
\hline & Primary & 59 & 3,62 & 0,68 & & & \\
\hline & Secondary & 30 & 3,72 & 0,70 & & & \\
\hline & High School & 38 & 3,70 & 0,82 & & & \\
\hline & Undergraduate & 22 & 3,60 & 0,99 & & & \\
\hline \multirow{5}{*}{ Persuasion Skill } & Illiterate & 9 & 2,85 & 1,05 & \multirow{5}{*}{$4-170$} & \multirow{5}{*}{1,82} & \multirow{5}{*}{, 126} \\
\hline & Primary & 63 & 3,34 & 0,77 & & & \\
\hline & Secondary & 37 & 3,57 & 0,87 & & & \\
\hline & High School & 43 & 3,44 & 0,85 & & & \\
\hline & Undergraduate & 23 & 3,14 & $1, \mathrm{OO}$ & & & \\
\hline \multirow{5}{*}{ Trustworthiness } & Illiterate & 9 & 4,53 & 0,42 & \multirow{5}{*}{$4-170$} & \multirow{5}{*}{1,28} & \multirow{5}{*}{,279 } \\
\hline & Primary & 63 & 4,01 & 0,56 & & & \\
\hline & Secondary & 37 & 4,09 & 0,74 & & & \\
\hline & High School & 43 & 4,03 & 0,76 & & & \\
\hline & Undergraduate & 23 & 3,94 & 0,67 & & & \\
\hline \multirow{5}{*}{ Responsibility } & Illiterate & 9 & 3,27 & 0,79 & \multirow{5}{*}{$4-170$} & \multirow{5}{*}{, 106} & \multirow{5}{*}{,980 } \\
\hline & Primary & 63 & 3,30 & 0,90 & & & \\
\hline & Secondary & 37 & 3,31 & 0,96 & & & \\
\hline & High School & 43 & 3,41 & 1,01 & & & \\
\hline & Undergraduate & 23 & 3,34 & 1,30 & & & \\
\hline
\end{tabular}

Note: $\mathrm{p}>0,05, \bar{x}:$ Mean. 
As understood in Table 8; the mean scores obtained in terms of Ability to Work with a Group [F (3-171) = 1.19; $>$ > .05]; Self-confidence $[\mathrm{F}(3-171)=2.12 ; \mathrm{p}>$.05] Problem Solving $[\mathrm{F}(3-171)=$, 78; $\mathrm{p}>$.05 $]$; Persuasion Skill $[\mathrm{F}(3-171)=0.58 ; \mathrm{p}>.05]$ Trustworthiness $[\mathrm{F}(3-171)=0.56 ; \mathrm{p}>.05]$; and Responsibility $[\mathrm{F}(3-171)=0.83$; $p>.05]$, which are the sub-dimensions of the Leadership Qualities Scale do not differ significantly in terms of number of siblings.

As can be seen in Table 10, participants' mean scores obtained from the sub-dimensions of ability to work with groups $[F(4-170)=1.01 ; \mathrm{p}>.05]$; Self-confidence $[\mathrm{F}(4-170)=0.29 ; \mathrm{p}>.05]$ Problem Solving $[\mathrm{F}(4-170)=0.16$; $\mathrm{p}>.05]$; Persuasion Skill $[\mathrm{F}(4-170)=1.82 ; \mathrm{p}>.05]$ Trustworthiness $[\mathrm{F}(3-171)=1.28 ; \mathrm{p}>.05]$ and Responsibility $[\mathrm{F}(3-171)=0.10 ; \mathrm{p}>$.05 $]$ do not differ significantly in terms of the education levels of the mothers of the students.

Table-10. Comparison of the leadership characteristics sub-dimension scores of Akdeniz University Faculty of Sport Sciences students according to the education level of fathers of the students.

\begin{tabular}{|c|c|c|c|c|c|c|c|}
\hline Dimensions & Father Education Status & $\mathbf{N}$ & $\bar{X}$ & $\mathbf{S}$ & sd & $\mathbf{F}$ & $\mathbf{p}$ \\
\hline \multirow{6}{*}{$\begin{array}{l}\text { Ability to Work } \\
\text { with a Group }\end{array}$} & Illiterate & 3 & 4,53 & 0,25 & \multirow{6}{*}{$5-169$} & \multirow{6}{*}{,613 } & \multirow{6}{*}{,690 } \\
\hline & Primary & 44 & 3,91 & 0,56 & & & \\
\hline & Secondary & 42 & 3,92 & 0,72 & & & \\
\hline & High School & 54 & 3,89 & 0,76 & & & \\
\hline & Undergraduate & 30 & 4,02 & 0,63 & & & \\
\hline & Master & 2 & 3,95 & 0,21 & & & \\
\hline \multirow{6}{*}{ Self-confidence } & Illiterate & 3 & 3,25 & 0,12 & \multirow{6}{*}{$5-169$} & \multirow{6}{*}{, 825} & \multirow{6}{*}{, 534} \\
\hline & Primary & 44 & 3,46 & 0,56 & & & \\
\hline & Secondary & 42 & 3,66 & 0,70 & & & \\
\hline & High School & 54 & 3,68 & 0,81 & & & \\
\hline & Undergraduate & 30 & 3,67 & 0,75 & & & \\
\hline & Master & 2 & 3,87 & 0,00 & & & \\
\hline \multirow{6}{*}{ Problem Solving } & Illiterate & 3 & 3,53 & 0,70 & \multirow{6}{*}{$5-169$} & \multirow{6}{*}{,461 } & \multirow{6}{*}{, 805} \\
\hline & Primary & 41 & 3,54 & 0,65 & & & \\
\hline & Secondary & 33 & 3,63 & 0,75 & & & \\
\hline & High School & 49 & 3,72 & 0,76 & & & \\
\hline & Undergraduate & 30 & 3,76 & 0,93 & & & \\
\hline & Master & 2 & 3,30 & 0,98 & & & \\
\hline \multirow{6}{*}{ Persuasion Skill } & Illiterate & 3 & 2,44 & 0,83 & \multirow{6}{*}{$5-169$} & \multirow{6}{*}{1,11} & \multirow{6}{*}{, 354} \\
\hline & Primary & 44 & 3,30 & 0,68 & & & \\
\hline & Secondary & 42 & 3,38 & 0,88 & & & \\
\hline & High School & 54 & 3,43 & 0,90 & & & \\
\hline & Undergraduate & 30 & 3,44 & 0,94 & & & \\
\hline & Master & 2 & 2,66 & 1,88 & & & \\
\hline \multirow{6}{*}{ Trustworthiness } & Illiterate & 3 & 3,48 & 0,80 & \multirow{6}{*}{$5-169$} & \multirow{6}{*}{.520} & \multirow{6}{*}{, 761} \\
\hline & Primary & 44 & 3,32 & 0,66 & & & \\
\hline & Secondary & 42 & 3,61 & 0,81 & & & \\
\hline & High School & 54 & 3,28 & 0,93 & & & \\
\hline & Undergraduate & 30 & 3,44 & 0,88 & & & \\
\hline & Master & 2 & 3,66 & 0,97 & & & \\
\hline \multirow{6}{*}{ Responsibility } & Illiterate & 3 & 3,00 & 0,50 & \multirow{6}{*}{$5-169$} & \multirow{6}{*}{, 549} & \multirow{6}{*}{,739 } \\
\hline & Primary & 44 & 3,43 & 0,83 & & & \\
\hline & Secondary & 42 & 3,15 & 0,92 & & & \\
\hline & High School & 54 & 3,37 & 1,01 & & & \\
\hline & Undergraduate & 30 & 3,43 & 1,26 & & & \\
\hline & Master & 2 & 3,00 & 0,99 & & & \\
\hline
\end{tabular}

Note: $\mathrm{p}>0,05, \bar{x}:$ Mean.

As seen in Table 10, participants' mean scores obtained from the sub-dimensions of ability to work with groups $\left[\mathrm{F}_{(5-169)}=0.61 ; \mathrm{p}>\right.$.05 $]$; Self-confidence $\left[\mathrm{F}_{(5-169)}=0,82 ; \mathrm{p}>\right.$.05 $]$; Problem Solving $\left[\mathrm{F}_{(5-152)}=0,46 ; \mathrm{p}>\right.$.05 $]$; Persuasion Skill $\left[\mathrm{F}_{(5-169)}=1,11 ; \mathrm{p}>\right.$.05]; Trustworthiness $\left[\mathrm{F}_{(3-171)}=0,76 ; \mathrm{p}>.05\right]$; and Responsibility $\left[\mathrm{F}_{(3-171)}=0,73 ; \mathrm{p}>.05\right]$ do not differ significantly in terms of the education levels of the fathers of the students.

\section{Discussion and Conclusion}

Students' general leadership levels are high. There was no difference between the leadership levels of the students in terms of gender, class, number of siblings, education status of parents, and places of accommodation. In addition, there is a difference in terms of the students' department. The students of the sports management department have a higher level of leadership than the students of other departments.

When the leadership levels of the students are examined, it will be seen that the general leadership levels of the students (arithmetic mean: 104.38) are high Table 1.

In terms of leadership levels according to demographic characteristics; In terms of students' gender, women have higher leadership levels; fourth-graders in terms of the class have higher leadership levels; in terms of the number of siblings, those with 1-2 siblings have a higher leadership level, in terms of the department, the sports management department has a higher leadership level, in terms of mother's educational status, those whose mothers are secondary school graduates have a higher leadership level, fathers with an undergraduate degree in terms of educational status are higher, have a leadership level, in terms of the place of accommodation, it can be said that those who stay in the apartment have a higher leadership level Table 2.

The insistence absence of women in leadership roles in North America has attracted the attention of authors in the academic literature. There are no women on the list of the 25 most influential Canadian business leaders recently in Report on Business in Canada (Loughlin \& Arnold, 2007). 
Among Fortune 500 companies in 2004, the rate of women in executives was around 8\% (Cappelli \& Hamori, 2005). However, when we look at the process, there have been significant changes in the number of women in assumed leadership positions in the USA in the past 30 years. The number of female managers increased from $18 \%$ in 1972 to $45 \%$ in 2000 .

When we look at the levels of the students' leadership sub-dimensions, it can be said that the levels of selfconfidence, ability to work with a group, trustworthiness, persuasion skill, problem-solving, and responsibility are high Table 3.

According to Cohen (2014) some students who like risky, exciting, and dangerous experiences during their university years feel the need to stand out from their peers, express themselves, show that they are different, make their own decisions, and stand behind their decisions. When the studies on leadership are examined in the literature, it is seen that the researchers have reached similar results.

When looking at the difference between the students' departments and the leadership and leadership subdimensions, it was seen that there was a significant difference between the leadership levels of the students and their departments $(p<0.05)$. It has been determined that the students of the sports management department have more leadership characteristics than the students of the other departments, on the other hand, the students of the recreation department also have fewer leadership characteristics than the students of the other departments (Table 4). There is a significant difference between the self-confidence levels of students and their departments $(p<0.05)$. Teaching department students have higher self-confidence than other department students. On the other hand, the students in the recreation department have less self-confidence than the students of other departments. There is a significant difference between the responsibility levels of the students and their departments $(p<0.05)$. The students of the department of sports management have more responsibility than the students of other departments. On the other hand, the students of the coaching department also carry less responsibility than the students of the other departments Table 4.

When the studies about the department and leadership are examined in the literature, it is seen that the researchers have reached different results. There are also studies where leadership orientation varies according to departments (Ozturk, 2017).

In terms of sub-dimensions of leadership; There is no difference in the sub-dimensions of the leadership level in terms of the number of siblings, education status of parents, and place of accommodation. In the dimension of selfconfidence, the students of the teaching department know better what they want as leaders, can do more than their goals, fight harder with difficulties, fight harder for their ideals, work adequately to achieve their goals, and look to the future with more confidence.

In the study, there is a difference between the responsibility levels of the students and their departments. Students of the department of sports management are more responsible for the welfare of others, more concerned with social problems, work more for their country, respect the rights of others, and are more aware of the obligations they bear. They bear more responsibility.

According to the results of the study, there is a significant difference between the gender of the students and their level of reliability. Female students have more integrity and values in their personal behavior and actions than male students. It can be said that female students are more reliable because their moral characters show more solidity. Female students will be able to interact more easily with those around them than male students, as they will provide more self-confidence behavior. It can be said that female students can establish more intimate relationships based on helping others, sharing troubles, and listening and trust.

According to this; self-confidence levels of coaching, sports management, and recreation department students; the level of responsibility of the students of teaching, coaching, and recreation departments; reliability levels of male students; first-grade students' persuasion skills should be increased. For these reasons, additional courses on self-confidence, persuasion skill, reliability, and responsibility should be added or this need should be met with seminars.

\section{References}

Adacay, F. (2014). Gender and development. Bursa: Ekin Publications.

Adair, J. (2003). The Conscise Adair on leadership. London: Thorogood.

Adair., J. (2011). The john adair lexicon of leadership: The definitive guide to leadership skills and knowledge. London Kogan Page Limited.

Akpinar, S., Bayansalduz, M., \& Toros, T. (2012). The study on job satisfaction levels of secondary education teachers in respect of some variables. International Journal of Academic Research, 4(1), 134-138.

Bayansalduz, M. (2012). Analyzing the relationship between task and ego orientation, collective efficacy and perceived coaching behavior: A research on footballers. Energy Education Science and Technology Part B-Social and Educational Studies, 4(1), 48 1-494.

Bayansalduz., M. (2014). An investigation into the state-trait anger expression level of taekwondo students attending high school. The Anthropologist, $18(3), 921-926$.

Bayansalduz., M., Afyon, Y. A., Kepoglu, A., Dalli, M., \& Mulazimoglu, O. (2014). Examination of self-leadership characteristics of football coaches. Procedia-Social and Behavioral Sciences, 152(7), 500-502.

Baykal, D. (1995). A research on leadership styles in organizations and leadership styles of trade union managers. Istanbul University Master Thesis.

Bingol, E., \& Bayansalduz, M. (2016). Evaluating the level of exercise dependence and psychological resilience of athletes from different branches. The Anthropologist, 24(3), 827-835.Available at: https://doi.org/10.1080/09720073.2016.11892079.

Cacioppe, R. (1997). Leadership moment by moment! Leadership \& Organization Development Journal, 8(7), 335-345.Available at: https://doi.org/10.1108/01437739710190648.

Can, Y., Soyer, F., \& Bayansalduz, M. (2009). Examining the relationship between job satisfaction of athletes and their feelings of organizational commitment. Nigde University Physical Education and Sport Sciences Journal, 3(3), 228-238.

Cansoy, R., \& Turan, S. (2016). Youth leadership traits scale: Reliability and validity study. Turkish Education Journal, 1(1), 19-39.

Cappelli, P., \& Hamori, M. (2005). The new path to the top. Harvard Business Review, 83(1), 25-32.

Cohen, A. D. (2014). Strategies in learning and using a second language: Routledge.

Derks, J., Lee, N. C., \& Krabbendam, L. (2014). Adolescent trust and trustworthiness: Role of gender and social value orientation. Journal of Adolescence, 37(8), 1379-1386.Available at: https://doi.org/10.1016/j.adolescence.2014.09.014.

Dugan, J. P., \& Komives, S. R. (2007). Developing leadership capacity in college students: Findings from a national study. A Report from The Multi-Institutional Study of Leadership. College Park, MD: National Clearinghouse for Leadership Programs.

Eraslan, M., Ozmaden, M., Bayansalduz, M., Goktepe, M., \& Koc, I. (2015). Investigation of the level of assertiveness in hearing-impaired athletes according to various variables. International Journal of Multidisciplinary Academic Research, 2(2), 50-57.

Findikci, I. (2009). Servant leadership. Istanbul: Alfa Publication. 
Gezgin, S., \& Yalcin, S. (2018). Leadership and communication ”, (Ed: Suat Gezgin), Dialectic view to media and communication (pp. 29-47). Istanbul: Egitim Publication.

Hemphill, J., \& Coons, A. (1957). Development of leader behaviour description questionnaire ed. R.M.Stogill- A.E. Coons, Leadcr Be/iavioiir: its Descriptioii and Measurenient (pp. 7). Colombus: Ohio State University.

Karasar, N. (1999). Scientific research method. Ankara: Nobel Publication.

Konter, E., Ng, J., \& Bayansalduz, M. (2013). Revised version of sport courage scale for children. Energy Education Science and Technology: Social and Educational Studies Part B, 5(1), 331-340.

Loughlin, C., \& Arnold, K. A. (2007). Seeking the best: Leadership lessons from the military. Human Resource Management, 46(1), 147-167.

Northouse, P. G. (2010). Leadership: Theory and practice (5th ed.). CA: SAGE Publications.

OECD. (2014). Pisa 2012 results: Creative problem solving; students' skills in tackling real-life problems (Vol. 5). Pisa: OECD Publishing.

Ozturk, K. E. (2017). Examining the leadership orientations and self-confidence behaviors of physical education and sports college students. Master Thesis Inonu University Health Sciences Institute, Malatya.

Rauch, C., \& Behling, O. (1984). Functionalism: Basis alternate approach to the study of leadership, ed. J.G.Hunt-D.M.Hosking, C.A Schriesheim, R.Stewart, Leaders and Managerk: International perspectives on managerial behaviour and leadership (pp. 46). New York: Pergamon Pres.

Sahin, T. (2019). The effect of positive teacher-student relationship on physical education classes in secondary school students. Internetional Jounarl of Sport Cultere and Science, $7(2), 42-52$.

Sisman, M. (1997). Raising future leaders and leadership in education ", 21 st Century Leadership Symposium (pp. 162). Istanbul: Naval Academy.

Soyer, F., Bayansalduz, M., \& Toros, T. (2012). Satisfaction of psychological needs and intrinsic motivation for sport in university students. Energy Education Science and Technology Part B-Social and Educational Studies, 4(4), 25 17-2522.

Tannenbaum, R., Weschler, I. R., \& Massarik, F. (1961). Leadership and organization. New York: McGraw-Hill.

Yukl, G. A. (2010). Leadership in organizations (7th ed.). New Jersey: Prentice. 